\title{
Lorrie Moore collection, 'A Little Ethnic Kink Is Always Good to See": Jewish performance anxiety and anti-passing in the fiction of Lorrie Moore
}

Article

Published Version

Brauner, D. (2012) Lorrie Moore collection, 'A Little Ethnic Kink Is Always Good to See": Jewish performance anxiety and antipassing in the fiction of Lorrie Moore. Journal of American Studies, 46 (3). pp. 581-602. ISSN 1469-5154 doi: https://doi.org/10.1017/S0021875811001940 Available at https://centaur.reading.ac.uk/25201/

It is advisable to refer to the publisher's version if you intend to cite from the work. See Guidance on citing.

To link to this article DOI: http://dx.doi.org/10.1017/S0021875811001940

Publisher: Cambridge University Press

All outputs in CentAUR are protected by Intellectual Property Rights law, including copyright law. Copyright and IPR is retained by the creators or other copyright holders. Terms and conditions for use of this material are defined in the End User Agreement. 


\section{CentAUR}

Central Archive at the University of Reading

Reading's research outputs online 


\section{Journal of American Studies}

http://journals.cambridge.org/AMS

Additional services for Journal of American

Studies:

American

Email alerts: $\underline{\text { Click here }}$

Subscriptions: Click here

Commercial reprints: $\underline{\text { Click here }}$

Terms of use : $\underline{\text { Click here }}$

\section{Lorrie Moore Collection“A Little Ethnic Kink Is Always Good to See": Jewish Performance Anxiety and Anti-passing in the Fiction of Lorrie Moore}

\section{DAVID BRAUNER}

Journal of American Studies / Volume 46 / Issue 03 / August 2012, pp 581 - 602

DOI: 10.1017/S0021875811001940, Published online: 14 August 2012

Link to this article: http://journals.cambridge.org/abstract S0021875811001940

How to cite this article:

DAVID BRAUNER (2012). Lorrie Moore Collection"A Little Ethnic Kink Is Always Good to See": Jewish Performance Anxiety and Anti-passing in the Fiction of Lorrie Moore. Journal of American Studies,46, pp 581-602 doi:10.1017/

S0021875811001940

Request Permissions : $\underline{\text { Click here }}$ 


\title{
Lorrie Moore Collection "A Little Ethnic Kink Is Always Good to See": Jewish Performance Anxiety and Anti-passing in the Fiction of Lorrie Moore
}

\author{
DAVID BRAUNER
}

This essay explores the ways in which the performance of Jewish identity (in the sense both of representing Jewish characters and of writing about those characters' conscious and unconscious renditions of their Jewishness) is a particular concern (in both senses of the word) for Lorrie Moore. Tracing Moore's representations of Jewishness over the course of her career, from the early story "The Jewish Hunter" through to her most recent novel, $A$ Gate at the Stairs, I argue that it is characterized by (borrowing a phrase from Moore herself) "performance anxiety," an anxiety that manifests itself in awkward comedy and that can be read both in biographical terms and as an oblique commentary on, or reworking of, the passing narrative, which I call "antipassing." Just as passing narratives complicate conventional ethno-racial definitions so Moore's anti-passing narratives, by representing Jews who represent themselves as other to themselves, as well as to WASP America, destabilize the category of Jewishness and, by implication, deconstruct the very notion of ethnic categorization.

In an article published in the New Yorker in 1997, entitled "Chop Suey Xmas," Lorrie Moore wrote with characteristic wry humour about her unconventional domestic arrangements at Christmas:

Oy. The holidays with our two-year-old boy... Performance anxiety pervades the household. We have to do all the holidays if we do any: Hanukkah for my husband, Kwanzaa for my son, who is adopted and part African-American, and, of course, Christmas (I think in my Gentile-centric way) for everyone. Our family is an improvisation... I own a book on Kwanzaa. I've opened it, spotted a lot of illustrations of craft items to make at home, then shut it in a sweat. I need more help with this. My husband's holiday indifference now seems like laziness. He hasn't a clue when Hanukkah begins this year. I find myself saying loudly, "Why does the shiksa have to get out the menorah every year? Why does the shiksa always have to light the candles?" All our two-year-old wants out of the holidays is gum. ${ }^{1}$

Department of English Language and Literature, University of Reading. Email: d.brauner@ reading.ac.uk.

${ }^{\text {I }}$ Lorrie Moore, “Chop Suey Xmas," New Yorker, 22 Dec. 1997, 87. 
As is often the case in her fiction, the comedy of this piece is used to mediate profound questions of identity. Appropriating the all-purpose Yiddish exclamation "oy!," which has become a cultural shorthand for a certain kind of Jewishness, and using it as a single-word sentence, Moore begins the article uneasily poised between implicitly claiming the status of honorary Jew and parodying the eyeball-rolling dismay and self-pity of a thousand popular Jewish stereotypes, from Woody Allen's schlemiels to Maureen Lipman's Beattie. ${ }^{2}$ This uneasiness manifests itself elsewhere in the paragraph: although Moore claims that "performance anxiety pervades the household," it soon becomes clear that the anxiety is solely hers. If, as Moore claims, her son's only concern is whether he can get hold of some gum and her husband is indifferent, then her claim that "We have to do all the holidays if we do any" is tendentious. Indeed, the fact that she uses a phrase - "performance anxiety" - usually encountered in the context of male insecurity about sexual prowess suggests that the pressure Moore feels to satisfy the expectations of her husband and son is self-imposed. In this context, the detachment and disinterest of her husband and son only exacerbate her fears that she will not be able to keep up the traditions to which she feels each belongs. And this is where the central irony of the passage lies: that in her anxiety to be sensitive to the ethnicity of her husband and son - her determination not to be too "Gentile-centric" she appears to be imposing on them identities that are more the product of her liberal values than of any actual religious or cultural affiliations on their part. Her son, at only two years of age, is of course too young to make any conscious decision about whether he wishes to participate in an African religious ritual, but Moore's ambivalence about facilitating such participation (she buys the book on Kwanzaa but then "shut[s] it in a sweat," sensing that she is an interloper in this territory, that she will not be able to perform the role prescribed for her in the book with conviction) mirrors her ambivalence about her role as the wife of a Jewish man.

Moore distances herself from the role that she is performing here by using a phrase ("I find myself saying") that implies that her behaviour is somehow involuntary, and the questions she ostensibly addresses to her husband - "Why does the shiksa have to get out the menorah every year? Why does the shiksa always have to light the candles?" - are rhetorical ones, expressions of mockindignation not intended to elicit a response. Nonetheless, the passage itself

\footnotetext{
${ }^{2}$ Beattie (punning on "BT," the abbreviation for British Telecom) was a Jewish mother played by Lipman, a comedienne and actress, in a long-running television advertising campaign during the r980s. In one campaign with the tag line "Keeping in touch" she is depicted addressing a photograph of her son, reproaching him sardonically for not ringing her ("You've got a phobia... You're telephobic"). Then there is a cut to the son leaving a message on her answering machine, after which Beattie is seen talking once more to the photograph: "It's a pleasure to hear your voice [Pause.] A little more often wouldn't hurt."
} 
provides an implicit answer, namely that her husband simply does not care about observing Hanukkah, as his ignorance about the dates of the festival (which shift every year in accordance with the lunar Jewish calendar) seems to confirm. The very fact that he has married Moore, a non-Jewish woman, suggests that he is unlikely to be a particularly devout Jew, since there exists within orthodox Jewish communities a strong injunction against what is commonly referred to as "marrying out" (an injunction stronger for men than for women, since Judaism is a matrilineal faith). Moreover, if he were observant, Hanukkah would not loom as large for him as Christmas does for churchgoing Christians; it is a very minor Jewish festival that has gained disproportionate prominence in Western society by virtue of its proximity to Christmas. Finally, that Moore refers to herself here as "the shiksa" is, in the context of the argument I want to pursue, the most significant detail of the passage, since, the comic tone notwithstanding, it implies not only that she sees herself as an inauthentic participant in the Hanukkah rituals - an impostor in this Jewish drama, as much as in the African one of Kwanzaa - but also that the role she fulfils more naturally is that of the Gentile temptress who seduces the Jewish man from the righteous path. "Shiksa" is a pejorative Yiddish term for a non-Jewish woman who seduces a Jewish man; "the shiksa" is a literary type that can be traced from Delilah in the Old Testament through to the sexually predatory, emasculating figures who recur frequently in male-authored Jewish fiction in the postwar era. ${ }^{3}$ Paradoxically, then, Moore's very desire to create a multi-denominational Christmas in which religious and cultural difference is respected results, in this opening paragraph of her essay, in her stereotyping her husband as The Jew, her son as The African American and herself as The Shiksa.

As Alison Kelly has pointed out in her excellent book Understanding Lorrie Moore (2009), the performance of identity is a central preoccupation of much of Moore's work, ${ }^{4}$ but I want to suggest that the performance of Jewish identity (in the sense both of representing Jewish characters and of writing about those characters' conscious and unconscious renditions of their Jewishness) is a particular concern (in both senses of the word) for her. More particularly, Moore's representation of Jewish self-fashioning, and her frequent juxtaposition of it with other types of alterity, such as those invoked in "Chop Suey Xmas," can be read as participating in what Lori Harrison-Kahan calls "the current trend to convey the social construction of race through the metaphorics of performance," "deploy[ing]

${ }^{3}$ Madeleine Pontritter in Saul Bellow's Herzog (1 964) and Maureen Tarnopol in Philip Roth's My Life as a Man (1974) are typical examples.

${ }^{4}$ See Alison Kelly, Understanding Lorrie Moore (Columbia: University of South Carolina Press, 2009), I I I-I6, hereafter cited parenthetically in the text. 
Jewishness to ... challenge [the] binary configurations" of conventional discourses of racial difference. ${ }^{5}$ Although Harrison-Kahan is writing about two contemporary passing narratives whose protagonists shift between black and Jewish subject positions (Danzy Senna's novel Caucasia (1998) and Rebecca Walker's memoir Black, White and Jewish (200I)), her formulations can equally be applied to Moore's fiction. In "The Wrath of Athena," her review of Philip Roth's novel The Human Stain (2000), whose protagonist is a lightskinned African American man who spends most of his life passing as a Jew, Moore observes that "Roth has given us a man struggling with a truly independent way of being Jewish: pretending to be Jewish. Being Jewish, for

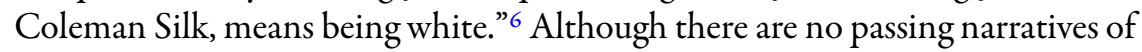
this kind in her own fiction, Moore's Jewish characters tend to behave as though they are passing and in so doing they deconstruct the very notion of what Jewishness is. Their anxious peformance of Jewishness might in fact be read as a sort of anti-passing, in that they feel compelled to appropriate for themselves an ancestral Jewishness which, at the same time, they perceive as inauthentic in the context of their modern secular American lives, whereas the protagonists of conventional passing narratives disavow an ancestral identity that they nonetheless feel, at some level, to be more authentic than the one they have assumed. In this sense, Moore's "Jewish" fiction can be read as an oblique commentary on, or reworking of, the passing trope. Moreover, because Jewishness, in Harrison-Kahan's words, "simultaneously signifies whiteness and racial otherness" (22) - a multivalency that Moore implicitly criticizes Coleman for failing to recognize - her representation of Jewishness and its relation to other ethnicities in her fiction "reveals identification itself to be an ambivalent process," thereby "destabilizing categories of identity" (25).7

There are fleeting references to Jewish characters in a number of the stories in Moore's first book, Self-Help (1985): the young narrator of "The Kid's Guide to Divorce" twice mentions a Julie Steinman who appears to be her best friend; Riva, the unhinged narrator of "To Fill," who has been embezzling from her employers, refers at one point to "Mrs Rosenbaum, our best charge customer" and to altering the receipts of another customer, Ann Klein; and the unnamed narrator in "What Is Seized" finds a number of photographs of her mother and an old boyfriend, Jacob Fish, one of which was taken "on

${ }^{5}$ Lori Harrison-Kahan, "Passing for White, Passing for Jewish: Mixed Race Identity in Danzy Senna and Rebecca Walker," MELUS, 30, I (Spring 2005), 19-48, 21, 22, hereafter cited parenthetically in the text.

${ }^{6}$ Lorrie Moore, "The Wrath of Athena," review of Philip Roth, The Human Stain, New York Times Book Review, 7 May 2000, 7-8, 7.

${ }^{7}$ I would like here to acknowledge the helpful suggestions made by Heidi MacPherson, and by the anonymous reader of this piece, particularly in terms of clarifying the issues identified in this paragraph. 
New Year's Eve in a big hotel in the Catskills." ${ }^{8}$ Fish later turns up to the mother's funeral and his influence on her is also suggested by something the narrator says when she discovers another photograph, this time of her parents at a petrol station with an Esso sign with the "o" missing: "Yiddish for 'eat', my mother told me once," the implication being that the mother had discovered this through her association with Fish, her college sweetheart with whom she had spent four years before "mysteriously" leaving him (37). None of these characters is explicitly identified as Jewish, but their names are sufficiently ethnic-specific for the reader to make the inference. There are no Jews in Moore's second book, the experimental novel Anagrams (1987), but in her second collection of stories, Like Life (1990), one of the most substantial stories is entitled "The Jewish Hunter."

The opening line of the story - "This was in a faraway land" - invokes the conventions of fairytale, though the "land" turns out to be not a magical kingdom but the Mid-west. ${ }^{9}$ Likewise, the eponymous hunter is no mythical figure but a "farm lawyer" named Pinky Eliot, who is set up on a blind date with a New York poet, Odette, by a mutual friend, Laird (I I6). Laird warns Odette that Pinky is "not at all literary" and is unlikely to be familiar with his namesake, the poet T.S. Eliot (I I6). However, he does not mention that Pinky is Jewish, a fact that lends resonance to Laird's reference to T. S. Eliot, some of whose poetry is notoriously anti-Semitic. So it is that when Pinky accuses Odette of being an "East Coast snob" who "hat[es] the Midwest" and then asks her if she is Jewish, she assumes that her date is a "Nazi ... hillbilly" and replies, "No, I'm not Jewish ... Are you?" ( I I 8). When Pinky answers in the affirmative, adding by way of explanation, "Not many of us in this part of the world, so I thought I'd ask," Odette is wrong-footed (I I 8). Later, when he reaches across the table to touch the hair that she "had had ... permed into waves like ramen noodles the week before," observing that "A little ethnic kink is always good to see," she is disarmed (I I9).

The two embark on an affair. After their second night together, Odette "got up early and went to the closest thing there was to a deli and returned triumphantly with bagels and lox" (125-26). Apparently uncertain how to interpret this gesture (does she buy such archetypal Jewish fare in a bid to ingratiate herself, or to demonstrate her cosmopolitan credentials?), Pinky asks her if she "like[s] this sort of stuff," to which Odette replies: "Yup ... Eat it all the time" (I 26). Whether Odette's response is sincere is unclear, as is Pinky's motive in promising to "teach [Odette] some Yiddish words...tush and

\footnotetext{
${ }^{8}$ Lorrie Moore, Self-Help (London: Faber \& Faber, 1987), 51, 52; 145; 34, hereafter cited parenthetically in the text.

${ }^{9}$ Lorrie Moore, Like Life (London: Faber and Faber, I 990), i 16 , hereafter cited parethentically in the text.
} 
shmuck... And shiksa" ( 126 ). Is he performing a parody of the exotic Jewish other for the benefit of a woman to whom these Yiddish words will be no more mysterious than bagels and lox, or is he mocking her apparent assumption that, because he is a Jew, he will like Jewish food, by parroting the Yiddish often encountered in lazy Jewish stereotypes? To put it another way: is Pinky rebuking Odette for her preconceptions, as he did on their first date when he accused her of being an East Coast snob, or is his joke inclusively self-satirical, tantamount to an admission that she, as a New Yorker, is likely to be more familiar than he with some of the common cultural signifiers of Jewishness (bagels and Yiddish words that have entered the language, for example).

At times, Pinky certainly seems to feel that Odette resembles the conventional image of the Jew more than he does. For example, he draws attention to the animated gestures with which she accompanies her speech, asking, "Why are you always talking with your hands?... You think you're Jewish?" (I 26). Conversely, before taking her on a hunting trip that precipitates their only argument (Odette is sickened by Pinky's shooting of a deer), Pinky alludes to his own deviation from conventional Jewishness - and demonstrates a metafictional awareness of the oxymoronic quality of the title of Moore's story - conceding that "Jews aren't supposed to hunt" (I29). If Pinky subverts the stereotype of the cerebral, unathletic Jew by virtue of his ignorance of poetry and enthusiasm for blood sports, ${ }^{10}$ he also conforms to the conventional stereotype of the Jewish victim in his direct and indirect encounters with anti-Semitism.

Early in the story the narrator refers twice to a facial scar that disfigures Pinky, but the explanation of its origin is withheld until near the end of the story, and when it is disclosed it is accompanied by two further revelations:

Some guy called me a Jew, and I went after him ... He broke a bottle and dragged it across my face... Funny thing was, I had no idea that I was Jewish. My grandmother waited until the next day to tell me... You have to understand midwestern Jews: They're afraid of being found out. They're afraid of being discovered... As you probably know already, my parents were killed in the camps. $(138)$

Pinky's confession invokes two key touchstones of twentieth-century Jewish history: the impulse to assimilate (in many cases, as here, to the point of erasing all knowledge of Jewish ancestry from a younger generation), and the more literal attempt to obliterate all traces of Jewish identity that manifested itself in the form of the Holocaust. The revelation that Pinky had grown up ignorant of his ethnicity sheds light on the acute self-consciousness he displays

${ }^{10}$ See Stephen J. Whitfield, "Unathletic Department," in Jack Kugelmass, ed., Jews, Sports and the Rites of Citizenship (Urbana: University of Illinois Press, 2006), 5 I-7 I. 
earlier in the story. Having grown up (unwittingly) passing as a WASP, Pinky spends his adult life trying to reclaim a sense of Jewish identity by deliberately performing as a Jew. Ironically, his "real" identity appears inauthentic (hence Odette's misreading of his inquiry about her own ethnicity), a paradox that is only exacerbated by his clumsy attempts to establish his Jewish credentials, particularly with reference to the Holocaust.

When Pinky prefaces the revelation that his parents died in Nazi death camps with the phrase "As you probably know already," he is referring to an episode earlier in the story, when the two lovers had watched a video of a documentary on the final solution:

It was a tape called Holocaust Survivors, and the title flashed blood red on the television screen, as if in warning that it had no place there at all... It seemed at moments confused about what it was about, a confusion brought on by knowing exactly. (124-25)

When the tape starts to play, Pinky tells Odette that he "watch[es] this all the time" ( 124 ), but afterwards the only comment he offers is the bathetically banal "Heavy stuff" ( 125 ). On the one hand, what seems at the time to be morbid and perverse (Pinky puts on the tape straight after he has made love to Odette and they watch it in bed) might, with the benefit of hindsight, be read as traumatized reticence, a psychological scar to match the physical scar on Pinky's face, both wounds the legacy of the history of anti-Semitism. On the other hand, Pinky might be seen as exploiting what Alain Finkielkraut in The Imaginary Jew calls "the intoxicating power to confuse myself with the martyrs" conferred on him by the death of his parents. ${ }^{11}$ Describing his generation of Jews growing up in postwar France, Finkielkraut suggests that their efforts to identify with the dead of the previous generation served only to highlight the incommensurable gulf between them: "Our frantic masquerade sought to ... deny the gap between our enjoyment of baby-boom comforts and the momentous, terrifying events of the recent past. Through such acts of fictive intensity, we exorcised the vapidity of our lives" (2I). Finkielkraut's theatrical diction ("masquerade," "acts") seems peculiarly appropriate to Pinky's situation, as does his reference to the "vapidity" of his comfortable, bourgeois existence. In this light, Pinky's intrusive appropriation of the historical events of wartime Europe seems like a spurious attempt to perform a Jewish role that he does not actually inhabit, an anti-passing, or paradoxical attempt to pass for the identity that is ostensibly his own. Pinky's Jewish performance anxiety, together with the paradoxical description of the documentary itself, as exhibiting a confusion "about what it was about, a confusion brought on by knowing exactly," has a

${ }^{11}$ Alain Finkielkraut, The Imaginary Jew, trans. Kevin O'Neill and David Suchoff (Lincoln, NB: University of Nebraska Press, I994), I I, hereafter cited parenthetically in the text. 
resonance for Moore's treatment of Jewishness not just in this story but in her oeuvre more generally.

At one point in "The Jewish Hunter," Laird asks Odette about the progress of her relationship with Pinky, saying, "I thought you'd find him interesting," to which Odette replies, "Sure, anthropologically" (I 27). The title of the story suggests that Moore's interest in Pinky is also primarily anthropological, that it is a study of an exotic type of Jewish masculinity. This reading is reinforced by the fact that Moore returns repeatedly to the subject of relationships between Gentile women and Jewish men in her fiction, interrogating the ways in which the dynamics of such relationships are inflected by the anti-passing strategies of the Jewish man. The protagonist of Moore's next book, the novel Who Will Run the Frog Hospital? (1994), Berie Carr, is a French Canadian married to a Jewish man, Daniel. In fact, the very first thing that Berie, in her first-person narrative, says about him is, "He was Jewish, Socialist, half Hungarian." ${ }^{2}$ Daniel is a scientist carrying out research on the Tay-Sachs gene, for personal reasons as much as for scientific ones: both he and Berie are carriers (it is "what Jews and French Canadians have in common," quips Berie) and it is because of this that they are childless $(7 \mathrm{I})$. If Daniel's Jewishness is defined partly in genetic terms, it is also, like Pinky's in "The Jewish Hunter," signified in relation to the Holocaust.

Although he does not have the same familial connection to the destruction of the European Jews as does Pinky, Daniel shares with him a compulsion to allude to the spectre of the Holocaust, as becomes clear in an episode in the "Paris" section of Who Will Run the Frog Hospital?:

There is an Audrey Hepburn festival at one of the revival theatres on the Left Bank, and everywhere I see posters for it: Hepburn's wide eyes and mouth. "Have you ever noticed," Daniel has said, "that she looks like Anne Frank?" Now I feel as if I'm seeing pictures of Anne Frank all over town...

The flower beds are full of pansies whose triangular, black centers boast the mustache of Hitler himself. (75)

Here Daniel's apparently innocuous observation that he finds Audrey Hepburn's gamine appearance (partly the consequence of a period of nearstarvation that she underwent as a child during wartime) reminiscent of Anne Frank fulfils a similar function to the "Holocaust Survivors" tape that Pinky plays to Odette. ${ }^{\mathrm{I} 3}$ It is a way of communicating obliquely to his Gentile

${ }^{12}$ Lorrie Moore, Who Will Run the Frog Hospital? (London: Faber and Faber, 1995), 28, hereafter cited parenthetically in the text.

${ }^{13}$ The connections between Hepburn and Frank go further than Daniel's remark might suggest. Born in the same year as Frank, Hepburn also spent time as a child in the Netherlands during the German occupation, was always fascinated by her and was reputedly asked by Otto Frank to play her in the film version of the Diary released in 1959, an offer she declined because she felt that she was too old to play the young Anne convincingly. 
girlfriend the oppressive weight of what Berie refers to elsewhere as the "abominable history" of French collaboration with the occupying German forces during the Second World War, without explicitly discussing the subject (83). Marguerite, Berie's friend, observes elliptically that "everyone knows about the Nazis" (83), but whereas in North America Daniel is geographically and culturally distanced from the events of the Second World War, in Paris there is no such distance. Earlier in the novel, Daniel moves abruptly from expressing his enthusiasm for the Parisian climate ("I like the weather") to observing that it is "that Deportation Monument $[\mathrm{t}]$ hat tells you who the Parisians really are," ${ }^{4}$ going on to imply that there is something "genocidal" about the French reverence for those who can speak their language "without any accent!" (73). In this context, Daniel's apparent non sequitur about Anne Frank-the archetypal icon of Jewish suffering during the Holocaust - appears to be his (and Moore's) way of raising the subject of the Holocaust without explicitly naming it. Like the tape in "The Jewish Hunter," Daniel's comparison of Audrey Hepburn and Anne Frank seems confusing, but it is "a confusion brought on by knowing exactly" what it signifies. However, the awkwardness of Daniel's joke, yoking together genocide and the stereotype of the French pride in their language, like the jarring juxtaposition of his inconsequential observations about the weather with his invocation of the deportations of the Jews, suggests an uneasy desire to perform his Jewishness (to anti-pass), rather than an authentic interest in exploring his Jewish identity.

"The Jewish Hunter" ends with Odette returning to New York and implicitly acknowledging that she will never see Pinky again: she imagines, "From a long distance ... a man would phone to say, doubtfully, 'I should come visit on Valentine's,' history of all kinds, incongruous and mangling itself, eating its own lips" ( (14). Who Will Run the Frog Hospital? ends with Berie and Daniel still physically together, but emotionally estranged from each other, Berie reflecting, "Something, someone, keeps him, is kept, in some other corner of his life. I can't follow him there - where that is, a place of woundedness, we too are without each other" (146). In both cases, there are clear obstacles to the continuation of these relationships: in "The Jewish Hunter," the geographical distance that separates Odette from Pinky; in Who Will Run the Frog Hospital?, the legacy of bitterness and distrust left by Daniel's infidelities. There are also hints, however, that it is the very "ethnic kink" that initially attracts the lovers which ultimately becomes an obstacle that cannot be smoothed out - that the anxiety attending the performance of

${ }^{14}$ The Deportation Monument is a memorial to those Jews deported from Paris to concentration and death camps during the Second World War. 
the men's Jewishness makes the Gentile women into "shiksas" who cannot be accommodated in their historical narrative of victimization. The disturbing image of history as a deforming, self-cannibalizing mouth (a grotesque echo of Pinky's facial disfigurement) suggests that the "long distance" from which Pinky calls (a distance amplified by the fact that he is referred to here not by name but generically, by gender, as "a man") refers to a cultural as much as a geographical chasm. The doubts which infect and inflect Pinky's modal construction ("I should come visit," implying that the visit will not, in fact, take place) may betray not simply uncertainty about the feelings that Odette has for him, but also a sense of alienation rising from his inauthentic performance of ethnic difference. In this reading, the phrase "history of all kinds" functions as another oblique reference; a euphemism, in fact, for Pinky's status as the orphaned child of Jewish casualties of the Holocaust. Similarly, Berie's ambiguous formulation - which cannot determine whether it is something or someone keeping Daniel, or being kept by him - allows for the possibility that "the place of woundedness" to which she cannot gain access is a site of psychological scarring connected to Daniel's ethnicity, rather than to his philandering. In other words, the wound - which is reopened by Daniel's visit to Europe - may be the Holocaust itself, for which Anne Frank functions as a metonym. Like the Tay-Sachs gene, the history of antiSemitism is an invisible, but potentially destructive, inheritance for Jews of Daniel's generation: a legacy which they feel they must claim, while at the same time realizing that such a claim is disingenuous. Whereas Berie, as a fellowcarrier, can share Daniel's Tay-Sachs burden, as a Gentile she cannot empathize with his discomfort at being in Paris, with its "whiffs of sewage and police state," the stench of its wartime history still lingering in the air (4).

There is another Gentile-Jew relationship in Birds of America (1 999), the collection of stories that followed Who Will Run the Frog Hospital?, but in this case it is between two gay men. "What You Want to Do Fine" deals with the adventures on the road of Mack, a divorced Irish American former soldier, and Quilty, a blind Jewish American lawyer as archly camp as his namesake from Vladimir Nabokov's Lolita (1955). Quilty's Jewishness is hardly central to the story, but when it manifests itself it is usually in the form of self-conscious, theatrical humour. For example, Quilty pretends to read a "Trivial Pursuit" question that asks whether there is life on Mars before responding,

I think the answer is yes. Look at it this way: they're sure there are ice crystals. And where there is ice, there is water. And where there is water, there is waterfront property. And where there is waterfront property, there are Jews! Is

\footnotetext{
${ }^{15}$ Lorrie Moore, Birds of America (London: Faber and Faber, 1999), 154, hereafter cited parenthetically in the text.
} 
Here again, Harrison-Kahan's suggestion that Jewishness "functions as a kind of ethnic 'queerness'" (a suggestion more fully developed in the first chapter of Jonathan Freedman's Klezmer America) seems to be apposite: Quilty's performance of his Jewishness is intimately connected with his performance of his queerness, both identities disrupting social conventions and normative values. ${ }^{16}$ Later, petting Mack's hair roughly, so that his lover exclaims in pain, Quilty says, "I keep forgetting your hair is so Irish and sensitive ... We've gotta get you some good tough Jew hair" (156). Here Quilty's contraction of the adjective "Jewish" to "Jew" (with its anti-Semitic connotations), combined with his invocation of his lover's "Irish" difference, seems to be part of a performance that draws attention to his Jewishness preemptively, as though to test his own ability to (anti-)pass as the stereotypical Jew whose masculinity his homosexuality both subverts and confirms. ${ }^{17}$ In this sense, Quilty occupies a transitional position in Moore's gallery of Jewish characters, recalling Pinky's anxious performance of his Jewish identity for Odette in the earlier story "The Jewish Hunter," but also anticipating Ira's for his girlfriend, Zora, in Moore's later story, "Debarking" (2003).

As Alison Kelly points out, "Debarking" resembles "What You Want to Do Fine" in two respects: while the earlier story takes place against the background of the first Gulf War, the second Gulf War is the backdrop for "Debarking," and the friendship between Mack and Quilty is echoed in the later story by the friendship of Ira, the Jewish protagonist, and Mike, his Irish best friend (although the latter is not a sexual relationship, there is a moment when the two hold hands, displaying an intimacy unusual for platonic male friends). However, there is another thing the stories have in common, which Kelly does not consider: the ways in which Quilty and Ira anxiously perform their Jewish identities.

The protagonist of "Debarking," Ira, is a newly divorced middle-aged man whose wedding ring "had grown twistedly around [his finger] like a fucking happy challah." ${ }^{18}$ Introduced to an attractive divorcee, Zora, at a party hosted by Mike, Ira decides to ring her up to ask for a date, but to his dismay she does not at first remember him:

"Hi, Zora? This is Ira."

"Ira?"

"Yes. Ira Milkins."

${ }^{16}$ See Jonathan Freedman, Klezmer America: Jewishness, Ethnicity, Modernity (New York: Columbia Press, 2007), 39-93, hereafter cited parenthetically in the text.

${ }^{17}$ One of the staples of early Church-sponsored anti-Semitism was to claim that the Jewish male body was effeminate, as manifested in the myth of Jewish male menstruation. See Sander Gilman, Multiculturalism and the Jews (New York: Routledge, 2006), 122-24.

${ }_{18}^{8}$ Lorrie Moore, "Debarking," New Yorker, 22 Dec. 2003, available at www.newyorker.com/ archive/2003/I2/22/03I222fi_fiction, I-I 5, I, hereafter cited parenthetically in the text. 
"I'm sorry ... I don't know who you are."

..."We met last Sunday at Mike and Kate's?"

"Ira Ohhhhhhhhh - Ira. Yeah. The Jewish guy."

"Yeah, the Jew. That was me." (4)

The fact that Zora only belatedly recalls Ira as "the Jewish guy" does not bode well for the ensuing relationship and indeed, taken out of context, might be seen as evidence of anti-Semitism. Yet, given Ira's behaviour at the party at which they met, it is perhaps hardly surprising that Zora labels him in this way.

When Mike first invites him to what he calls a Lent dinner, Ira immediately adverts to his Jewishness, telling his friend, "I'm unclear on Lent. I mean, I know what the word means to those of us of the Jewish faith. But we don't usually commemorate these transactions with meals. Usually there's just a lot of sighing" (2). Taking his cue from Ira, Mike then explains, "It's almost Easter season and - well, hey, we could use a Jew over here," and Ira continues with his theme, promising to "re-enact the whole thing for you" and "come over and show you all how it's done" (2). The humorous tone of this reference to one of the oldest, and most persistent, causes of anti-Semitism (namely the belief, encouraged by the early Christian church, that Jews were responsible for the crucifixion of Christ) - like Moore's characterization of herself as "the shiksa" during the Christmas season - does not quite obscure a genuine uneasiness at the incongruous presence of the Jewish male at a Christian ritual.

At the party itself, Ira continues to expand on his theme:

He drifted back into the kitchen and, as he felt was required of him, shrieked at the pork. Then he began milling around again, apologizing for the crucifixion. "We really didn't intend it," he murmured. "Not really, not the killing part? We just kind of got carried away? You know how spring can get a little crazy, but believe me, we're all really, really sorry." (2)

Here there is a slightly hysterical edge to Ira's comic routine, which once again betrays an anxiety about how his performance will be received. The use of the first person plural (implying that Ira is speaking on behalf of all Jewry), the incongruous question marks (parodying the rising intonation prevalent among younger generations across the anglophone world, by virtue of which statements sound like inquiries) and the use of "really" as both qualifier ("Not really") and intensifier ("really, really sorry") all implicitly subvert the expression of remorse. However, the really telling detail is that Ira feels that his melodramatic reaction to seeing the pork in the kitchen (pork, of course, being a food forbidden to Jews) "was required of him." It seems that Ira has taken Mike's joke about needing to have a Jew present for their Easter celebrations literally; instead of simply being himself, Ira feels that he must fulfil a predetermined role - that of The Jew. The fact that he explicitly imposes this label on himself in his telephone conversation with Zora - she identifies him as "the Jewish guy" but Ira refers to himself as "The Jew" - and that he reprises 
the role during their first date, responding to the revelation that Zora hails from Kentucky with the non sequitur "Not a lot of Jews down there" (6), reinforces the sense that Ira feels constrained to conform to the preconceptions that he imagines others might have of him as a Jew - to antipass, in other words, as The Jew, rather than to be the secular Jewish man he really is.

Whereas in these earlier fictions Jewish performance anxiety tends to occur in the interactions between (typically male) Jewish characters and their (typically female) Gentile partners, in Moore's most recent novel, $A$ Gate at the Stairs (2009), it expresses itself in, and is expressed by, the novel's protagonist, Tassie Keltjin, a self-described "half-Jewish" college student halfheartedly pursuing courses at Troy liberal-arts college, who is hired in the Christmas vacation as a babysitter for a yet-to-be-adopted child. The phrase "half-Jewish" is in itself contentious, since, according to theological orthodoxy, Jewishness is passed on through the maternal line, so that Tassie, as the daughter of a Gentile father and Jewish mother, is in fact wholly Jewish, whereas her employer, Sarah Brink, also described as "half-Jewish" in the novel, is not Jewish at all, as her father is her only Jewish parent. However, Tassie's ambivalence towards her own Jewishness extends far beyond semantic ambiguity. Tassie's mother is, in one sense, the antithesis of the overinvolved, suffocating Jewish mother of popular myth. "[P] ractically blind," she is also metaphorically myopic in her child-rearing, confessing to Tassie that "as long as the place was moderately fire resistant, I'd deposit you anywhere." ${ }^{9}$ Tassie initially seems to attribute her mother's emotional detachment to her marriage to her father:

She was the only Jewish woman I'd ever known who felt like that. But she was a Jewish woman married to a Lutheran farmer named Bo and perhaps because of that had the same indifferent reserve the mothers of my friends had. (9)

If she shares with her neighbours an "indifferent reserve," her difference from them does not go unnoticed: Tassie reports that she is widely viewed with suspicion, as "an eccentric spouse of indeterminate ethnicity who slept too late for a farmer's wife and did not keep herself busy enough with chores" (20). The fact that the mother's ethnicity is perceived as "indeterminate," rather than specifically "Jewish," is revealing, both because of the quintessential indeterminacy of Jewishness itself (both black and white and neither, to some a religion, others a race and others a culture) and because this proves to be a novel that revolves around indeterminate ethnicities. Removed from the urban, nurturing community ordinarily

\footnotetext{
${ }^{19}$ Lorrie Moore, $A$ Gate at the Stairs (London: Faber and Faber, 2009), 9, 8, hereafter cited parenthetically in the text.
} 
associated with American Jews (following her father "in reluctant love ... out here to the country, to this farm"), Tassie implies, her mother's capacity for maternal devotion is somehow stunted. Yet it soon becomes clear that Tassie, far from excusing her mother's shortcomings as a parent, keenly resents her for them.

This resentment emerges clearly during her description of her visit home for Christmas, when Tassie finds herself "filled... with loathing" at her mother's histrionic displays of self-pity and nostalgia for the Christmases of her youth, when her mother had been more "game" (53). Lamenting the "painfully casual" nature of the family's seasonal rituals, paradoxically signified by the absence of traditional Jewish food ("no hamentaschen, no pfeffernüsse, no kringle"), Tassie speculates that perhaps "my mother, the keeper of ritual, had lost interest in this ostensibly Christian custom now that we had grown, and my father didn't really know how to take over" (54). Like the culturally confused Christmas that Moore describes in "A Chop Suey Xmas," yuletide festivities at the Keltjin household seem to involve an unorthodox mingling of Jewish and Christian tradition and to prosper or founder according to the efforts of the matriarch, in the face of a largely passive father figure whom Tassie describes as a "quasi drunk" (23):

My mother had baked a noodle kugel and instead of turkey had made a Christmas brisket [which she] ... brought ... in on a platter from the kitchen and ... swooped ... onto the table, barely missing my head. "Duck," she ordered me as she did this, and I let my head fall to one side.

"What is that?" asked my brother....

"You're the son of a Jewish mother," said my dad, "and you don't recognize brisket?"

"I do recognize brisket... But I thought she said it was duck." (62-63)

The play on the different meanings of the word "duck" here is typical of Moore (surely the most prolific and adept punner in postwar American fiction since Nabokov), but the episode as a whole, like the multicultural Christmas of Moore's own experience that it echoes, reveals anxieties about the juxtaposition of Jewish and Christian traditions that go beyond the unconventional Christmas Day fare. Though prefatory to a punch line, the careful formulation that Tassie's father uses to describe his son Robert's ethnicity, highlights the awkward self-consciousness that the subject elicits in the Keltjin family. Conspicuously avoiding Tassie's self-defining tag, "halfJewish," and rejecting the less equivocal "Jewish," the phrase "son of a Jewish mother" simultaneously emphasizes the boy's connection to his Jewish heritage and distances him from it: as the son of a Jewish mother the boy is technically Jewish, but as only the son of a Jewish mother, he is, by implication, not a Jew in his own right. 
The tension between these two meanings, and between the Jewish and Gentile traditions, resurfaces at the end of the novel, after Robert has been killed in action in Afghanistan, when the following exchange between Tassie's parents takes place:

"We never should have named him after you! Jews understand that. It's bad luck. Why did you want that so much?"

"I thought you meant it was bad luck for me! ... And I didn't mind that. I didn't mind about some old world hocus-pocus."

"Well, look at that old world hocus-pocus now." (294)

Here again is the juxtaposition of humour and suffering that is the keynote of Moore's fiction; the mother's recriminations are deflected by the comic misunderstanding about the nature of the Jewish prohibition on naming children after living relatives, but at the same time the father's mockery of the superstitious custom is deflated by the mother's pathetic conviction that her misgivings have been vindicated. This is further complicated, however, by the fact that the mother's reversion, in her raw grief, to the Jewish traditions that she had rejected through her marriage (manifested not simply in her invocation of the naming injunction, but also in the fact that she has "covered all the mirrors in the house with pillow-cases and scarves") is another example of what I have been calling anti-passing, since the role of the grieving Jewish mother that she embraces here seems inauthentic in the context of the life she has led. As Tassie (and by extension Moore) presents it, Tassie's mother's recidivism is a tragicomic development: tragic because of the depth of the suffering to which it testifies, comic because of the incongruity of the orthodox pieties she espouses with the secular, unorthodox, culturally hybridic world of the Keltjins (295).

This cultural hybridity is echoed in the other dysfunctional family at the centre of The Gate of the Stairs, in which the father, Edward Thornwood, is a semi-detached Gentile scientist with a roving eye; the mother, Sarah Brink, a "half-Jewish" chef; and the child an adopted, part African American girl. When Tassie meets Sarah for the first time, the older woman observes that "I'm old enough to be your...", leaving the sentence incomplete while she "processe[d] her own amazement" (23). Tassie is disconcerted by the thought, confessing that she "didn't want, even in my imagination, even for a second, to conflate this sophisticated woman with my mother" (23). Later, she tries "to think of who Sarah Brink reminded me of" but concludes that "it wasn't anyone I'd actually met" (24). If her vehemence suggests a case of protesting too much ("even in my imagination, even for a second"), then Sarah's dubious parenting skills confirm that the resemblance is stronger than Tassie would like to acknowledge: Sarah leaves her biracial adopted daughter, variously named Mary, Mary-Emma and Emmie, almost exclusively in Tassie's care while she is occupied with running her restaurant business, and the central 
revelation of the novel is that she was partly responsible for the death of a biological son many years previously. ${ }^{20}$

If on one level Sarah is a surrogate mother for Tassie, on another she is her secret sharer. Early on in the novel Tassie, having momentarily "glimpsed ... the girl I imagined she once was," ponders how such a "nice, attractive girl ... became a lonely woman with a yarny shmatte on her head, became this, whatever it was" (36). The use of Yiddish here (shmatte) and the curious attenuation of the description into a vague set of impersonal pronouns ("this," "it") foreshadows the disclosure of Sarah's ethnicity:

"You know, my father was Jewish, so I'm half Jewish -"

"So am I!" I burst forth, as if we were random transplants from the farthest reaches of Sri Lanka. I'd never met anyone half Jewish before, and for some reason it excited me: a peculiar but benign hybrid is what I felt like, and it seemed fantastic to know of someone else freakishly, well, neutered in exactly this same way. (I29)

Notwithstanding her apparent enthusiasm at the connection between herself and Sarah, and her claim that she thinks of her own hybridity as "benign," Tassie's diction here ("transplants," "peculiar," "freakishly" and "neutered") connotes dislocation and disfigurement, mutilation and monstrosity. As such, it reveals an anxiety that is reinforced by her hammy performance of kinship, indicated in the exclamation mark and archaism that follow her announcement of her own status as a half-Jew: "So am I!', I burst forth." In fact, what Sarah and Tassie share - both with each other, and with the other Jewish characters in Moore's fiction - is not so much a clear sense of ethnic identity as a vague intimation of difference within difference, an uneasy self-consciousness of a Jewishness they do not feel they own, and a compulsion to perform that Jewishness as part of an anti-passing ritual. This sense of indeterminate ethnicity is something that extends beyond Tassie and Sarah, and Tassie's mother, to encompass two other key figures in the novel: Tassie's boyfriend and Emmie.

The first mention of Emmie in the novel immediately establishes how fraught is the issue of her ethnicity. Sarah intially describes her as "black," then modifies this to "Part black," prompting Tassie to recall a girl named Rachel, a freshman in her dorm who was known to her friends as "Inter-Rachel" because of her mixed parentage (80). When Sarah meets Emmie and exclaims at her beauty, she is warned, by an adoption agent who is herself the mother of a "biracial son," that Emmie will "darken up" as she gets older (86). When she questions Bonnie, the birth-mother, to confirm that her daughter is "halfblack," she replies "More like a quarter," before going on to speculate that her

${ }^{20}$ She fails to dissuade her husband from leaving the boy by the roadside on a motorway. Initially intended to be a temporary punishment for his persistent misbehaviour in the back of the car, the incident becomes a tragedy when the boy runs out into traffic and is killed. 
father might in fact have been "Italian" (90). When she is formally handed over to Sarah by her foster mother, she is described as "biracial AfricanAmerican" (I I 2). Later, Sarah forms a "support group" consisting of other "transracial, biracial, multiracial families," who refer to their offspring as children "of color" ( I 54). Finally, when she decides to abandon the experiment of raising Emmie (that she sees it this way is implicit in her comparison of herself and Edward to "canaries in ... [a] coalmine"), Sarah reverts to an essentialist nomenclature (and philosophy), rationalizing her decision to Tassie by claiming that Emmie "should be with black parents," who in turn protest on the grounds that she is "mixed" $(246,245)$.

The sheer proliferation of the terms used to describe the status of the families who comprise the "support group," like those invoked to define Emmie's ethnicity, demonstrates clearly how indefinable it is and how slippery and emotive is the discourse surrounding race in America. The almost obsessive concern with how black Emmie is (running the full gamut from simply "black," through "African-American," "interracial," "biracial," "mixed," "half-black," "quarter black," "partly black," to "Italian," i.e. not black at all) suggests that the old rule of hypodescent still operates in a de facto way in contemporary America. Moreover, these variations of designation, which are echoed in the different names given to her (and in those not given to her, since Sarah wonders whether she ought to have given her an African name, such as "Maya or Kadira or Tywalla") effectively deny her any autonomy or agency, objectifying her as the site of contested identity politics (249). As Tassie herself belatedly observes, "Everyone... called Mary-Emma by a slightly different name, like she was no one at all" (256). To put it another way: because Emmie is too young to construct an identity for herself, her identity is performed by others, for whom the indeterminacy of her ethnicity acts as a conduit for them to express their anxieties about their own identities.

This is made particularly clear in two moments in the novel: first, when Tassie notices that Sarah and Edward "were performing their marriage at me" (98); and second, when Tassie, towards the end of the novel, compares her "half-Jewishness" to the feeling of being a "part extraterrestrial, a mixed breed, a sci-fi tragic mulatto" (285-86, italics in original). Although characteristically couched in comic terms, the implication here is that Tassie, consciously or not, regards herself as occupying the same liminal territory, the same ethnic limbo, as Emmie. To put it another way, the debates surrounding Emmie's identity can be read as an externalized, explicitly articulated analogue of the implicit, internal conflicts that exercise Tassie throughout the novel. This is also true of Tassie's boyfriend.

After they first meet, Tassie begins to refer to the boy with whom she later begins an affair simply as "the Brazilian" (165). Later he is given a name, Reynaldo, but his ethnicity remains uncertain. Tassie describes the colour of 
his teeth ("cream"), his gums ("pale lox pink") (167) and his skin ("brown") (I68), but rather than defining his identity, these attributes merely reinforce the elusive nature of his origins, as does the scarf he wears round his neck ("black and white ... a print I thought of as Middle Eastern, though it could have been a Navajo tablecloth, for all I knew"), which functions as a metaphor for his own ambiguous identity ( 167 ). Like Emmie, the mystery of Reynaldo's identity is always connected to, but not resolved by, the colour of his skin. Unlike Emmie, however, he is able to exploit the ambiguity of his appearance, taking on a protean quality that destabilizes his selfhood. Once Tassie takes to dressing like "a costume party's idea of a terrorist" for her trysts with Reynaldo, wearing "an Egyptian scarab necklace," "Arabian Goddess perfume," "a clumsy blue ring made in the backstreets of Karachi" (I 84), and a muslin headscarf ("He thought I'd called it 'Muslim' rather than 'muslin'") (194), as well as attending 'Palestinian rall[ies]" (I9I) with him, the alert reader probably infers that "the Brazilian" is no such thing, but rather an Arab passing as a South American. Just as Tassie's emotional involvement with Emmie is intensified by their shared "mixed" ethnicity, so her desire for intimacy with Reynaldo appears to be at least partly the product of an unconscious identification with him. So when he finally admits his deception (without, however, revealing his real name or nationality), before fleeing from the college authorities, who have identified him as a terrorist suspect, Tassie's sense of betrayal is exacerbated by the fact that he labels her as unequivocally other, telling her she is "innocent. Especially for a Jew" (205). The irony of his inflexible imposition of ethnic identity on Tassie, then, resides not just in her failure to pin him down similarly, but in her ambivalent sense of her own Jewishness.

Whenever Tassie mentions her soi-disant half-Jewishness, it is in an awkwardly humorous context, whether identifying herself to Reynaldo as " $a$ quasi-Jew" (italics in original), attributing to it the inclination "to think of Jesus not as the messiah but as, like, a celebrity" (98), or, in an episode that echoes a scene from Woody Allen's Annie Hall (1977), mishearing a waiter at Sarah's restaurant recommend "a skirt steak served with shiitake mushrooms and its own jew" (280). ${ }^{21}$ What makes Tassie's performance of Jewish difference a quintessential example of anti-passing is not just the anxiety (expressed in, and deflected by, humour) which accompanies it, but the fact that it is at the same time signified as different from conventional

\footnotetext{
${ }^{21}$ Woody Allen, Annie Hall (1977), available at www.script-o-rama.com/movie_scripts/a/ annie-hall-script-screenplay-woody.html. At one point the protagonist of Allen's film, Alvy Singer, complains to his friend, Rob, that, after "having lunch with some guys from NBC," one of them (the symbolically named Tom Christie, replied to his enquiry "Did you eat yet or what?" with an anti-Semitic jibe: “'No, didchoo?' Not, did you, didchoo eat? Jew? No, not did you eat, but Jew eat? Jew. You get it? Jew eat?"
} 
Jewish difference through the invocation of the archetypal Jew-who-was-not-aJew, Jesus, ${ }^{22}$ the use of the qualifying term 'quasi', and by the lower-case ' $j$ ' in 'jew' (as well as by the fact that the word is the product of misprision). Similarly, when Sarah refers to things Jewish, a familiar anxiety, masquerading as facetiousness, permeates her discourse. In the first instance she tells Tassie that she "knew someone in cooking school who was a blue-eyed Jew" whose "sperm was in great demand at the local sperm bank." The boy "was at first a funny story and then a kind of expression we all used: 'Gettin' over like a blueeyed Jew in a sperm bank"' (38). The second example occurs during one of the regular soirées organized by Sarah as a way of getting local parents of biracial children together to discuss their experiences. One night the conversation turns to the question of animal rights and the ethics of slaughtering animals for food. Someone poses the question of how best to dispose of chickens and Sarah interjects,

How to kill chickens: Enough to feed the planet? I mean, have we learned nothing from the Holocaust? Can't we just round them up and gas them?... That would express the Jewishness of the chickens - or do I mean the chickenness of the Jews? (200)

Although Sarah's intention is clearly satirical, her joke, invoking as it does the popular myth that Jews submitted meekly to their fate in the camps, and moreover being told to an audience whose number includes someone who had earlier complained of the injustice of "[w]ell-to-do Jewish grandchildren" receiving war reparations while "[i]n Ohio and Brazil there are grandchildren of Nazis who are truly destitute" ( 156 ), is, like Pinky's and Daniel's awkwardly incongruous allusions to the Holocaust, in questionable taste.

Sarah's remarks are overheard by Tassie, who is here an unreliable narrator not simply in the narratological sense but because she is eavesdropping from another room, so that she is not sure of who is speaking at any given time: she prefaces the speech about Jews and chickens with the line "And here I thought I heard Sarah's voice" (200). Even allowing for the uncertainties of attribution and fidelity - the secondhand mediation through the naive yet paradoxically knowing first-person narrator who is Tassie-this episode also raises the question of authorial complicity in this discourse of (half-)Jewishness. If, within the framework of the novel, Sarah's joke is an ill-judged attempt at satire, can the same be said if we consider it divorced from that context? After all, there are two authors of the joke and two audiences who receive it: Sarah

\footnotetext{
${ }^{22}$ Of course, the historical Jesus was unequivocally Jewish, but seen retrospectively, in terms of a Christianity conceived both as the fulfilment and rejection of Judaism, his Jewishness is often effectively erased.
} 
and her informal parenting group in the discourse of the novel, Moore and her readers outside it. Is Sarah the object of Moore's satire here, or is she the mouthpiece for it? Does that slippery and contentious old chestnut of literary criticism, authorial intention, matter here, or is the joke defensible or indefensible according to the particular values of a particular reader? These are intractable questions to which I do not pretend to have the answers. I would argue, however, that it is unlikely to be mere coincidence that such thorny issues of authorial tone are raised again and again in Moore's work when the subject of Jewishness is broached.

A number of reviewers of $A$ Gate at the Stairs suggested that its representation of the difficulties faced by white parents bringing up adopted black children reflected Moore's own experiences, but none speculated about the possible biographical significance of the novel's treatment of Jewishness. ${ }^{23}$ In the concluding chapter of Understanding Lorrie Moore, Alison Kelly suggests that the experiences of Sam, a boy in one of Moore's stories, "Paper Losses," might well owe something to those of her own son, before going on to strike a cautionary note:

This should not lure readers into either the biographical fallacy of scouring the work for clues to the life or its psychoanalytical corollary, what she [Moore] calls the "therapeutic fallacy," which suggests that "writers are cathartically working out their problems in their writing." ( 150$)$

The point is well made, and I certainly would not want to read Moore's work in crudely biographical terms; she is far too knowing a writer for such a reductive approach. On the other hand, Moore herself, while warning against what she calls "the misstep of biographical overreading," ${ }^{24}$ also concedes that all fiction draws, to a greater or lesser extent, on personal experience, ${ }^{25}$ that "one of the hazards of realism" is to invite interrogation of the relationship between life and art, and that even a naive reading of fiction as thinly veiled

${ }^{23}$ Helena de Bertodano, "Lorrie Moore interview," The Telegraph, www.telegraph.co.uk/culture/ books/authorinterviews/6256085/Lorrie-Moore-interview.html), accessed Dec. 2010. For example, Helena de Bertodano writes, "In her new novel - 'her most powerful yet', according to the New York Times - a central theme explores the experience of a white couple from a Midwestern college town who are in the process of adopting an African-American child. Moore and her ex-husband adopted their son, Benjamin (who is African-American), and the acuteness of some of the observations seems to be drawn from experience."

${ }^{24}$ Lorrie Moore, "A Pondered Life" (review of two biographies of Eudora Welty and four new editions of her work), New York Review of Books, 2 I Sept. 2006, available at www.nybooks. com/articles/r 9299 .

${ }^{25}$ Lorrie Moore, "Home Truths" (review of John Updike, The Early Stories 1953-1975), New York Review of Books, 20 November, 2003, available at www.nybooks.com/articles/ archives $/ 2003 / \mathrm{nov} / 20 /$ home-truths. In a review of a volume of John Updike's early short stories, Moore wrote that "Philip Larkin once said that novels are about others; poems are about oneself. One can imagine a short story falling somewhere in between." 
autobiography "looked at the right way is a compliment of the profoundest sort." ${ }^{26}$ At any rate, it seems to me that the persistently painful selfconsciousness with which her Jewish characters tend to perform their own Jewishness might be read as a metaphorical expression of her own feelings of displacement as an East Coast intellectual who has lived for many years as an exile in the Mid-west: all her Jewish characters are themselves exiles and/or misfits of one sort or another: a Mid-west Jewish "farm lawyer" and "hunter," an American Jew in Paris, a gay Jew on the road with his Irish lover, a Jew at an Easter party, a "half-Jewish" teenager from a "a small farm" with "no experience ... of the outside world" (4). If in one sense Moore's Jews are authorial surrogates, in another sense they might be read as versions of her estranged husband, their performance anxiety manifestations of a displaced anxiety on Moore's part about her own authorial performance of these roles, which in turn derives from her unease at performing the role of "the shiksa" in her failed marriage. The frequency with which Jewishness recurs in her work is in itself striking (I cannot think of another non-Jewish contemporary author in whose work it has a comparable prominence, with the possible exception of John Updike), but equally notable is the rhetorical strain which often accompanies it. Particularly conspicuous because of the characteristic poise of her prose, this strain suggests to me that Jewishness in Moore is never simply incidental or "a little ethnic kink" that might lend a particular twist to a story, but in fact is always invested with a peculiar intensity that manifests itself in a kind of performance anxiety on the part of character and author.

If Moore's preoccupation with Jewishness is partly autobiographical, it also enables her to intervene in contemporary debates about ethnicity and postethnicity. Although Jews make up only between I.4 and 2.5 percent of the total population of the US (the figures vary according to the criteria used to define Jewishness), they occupy a central position in the symbolic imagination of both blacks and whites in America because, paradoxically, they fit into neither and both camps. It is this equivocal position - compounded by the ambiguity of the term "Jewish" itself, which conflates racial, religious, ethnic and cultural characteristics - that, as Jonathan Freedman puts it, makes "the example of Jewishness powerfully and uniquely ... disrupt the certitudes and rigidities that mark not only American race thinking, but race thinking across the board" (195). At the end of $A$ Gate at the Stairs, Tassie moves in with a girl who describes herself as "a quarter African-American, a quarter Oneida, a quarter Czech, a quarter Irish" (3 I 2), but throughout Moore's fiction Jewishness fulfils a similar symbolic function, representing, and represented as, 


\section{David Brauner}

an ethnic kink that disrupts the neat demarcations of what David Hollinger has called the 'ethno-racial pentagon' and whose anxious performance implies the radical idea that it is possible to pass as a member not simply of another ethnicity, but of your own. ${ }^{27}$ Just as passing narratives complicate conventional ethno-racial definitions, so Moore's anti-passing narratives, by representing Jews who represent themselves as other to themselves, as well as to WASP America, destabilize the category of Jewishness and, by implication, deconstruct the very notion of ethnic categorization.

${ }^{27}$ See David A. Hollinger, Post-ethnic America: Beyond Multiculturalism (New York: Basic Books, 2005), 8. 